\section{SOI: $1.1 /$ TAS DOI: $10.15863 /$ TAS International Scientific Journal Theoretical \& Applied Science}

p-ISSN: 2308-4944 (print) e-ISSN: 2409-0085 (online)

Year: 2018 Issue: 09 Volume: 65

Published: $20.09 .2018 \quad$ http://T-Science.org

SECTION 31. Economic research, finance, innovation, risk management.

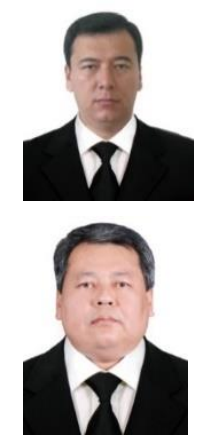

Ravshan Ibragimovich Nurimbetov Prof., Vice-Rector for Research at the Tashkent Architecture and Construction Institute

\section{Islambek Khalikovich Davletov $\mathrm{PhD}$, Head of Chair at the Tashkent Architecture and Construction Institute}

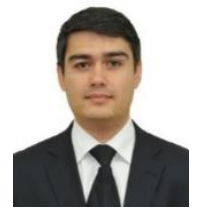

Tokhir Abdurashidovich Khasanov $\mathrm{PhD}$ Researcher Senior Lecturer at the Academy of Public Administration under the President of the Republic of Uzbekistan

\title{
IMPROVEMENT OF THE HOUSING CONSTRUCTION MANAGEMENT SYSTEM IN UZBEKISTAN
}

Abstract: In this article, the authors studied and analyzed the growth trend of the housing stock in the country, the reforms carried out and the results achieved in this sphere. And also, developed recommendations to optimize the housing construction on the basis of modern requirements.

Key words: housing fund, housing stock management, housing construction management, feature of housing construction.

Language: English

Citation: Nurimbetov RI, Davletov IK, Khasanov TA (2018) IMPROVEMENT OF THE HOUSING CONSTRUCTION MANAGEMENT SYSTEM IN UZBEKISTAN. ISJ Theoretical \& Applied Science, 09 (65): 70-74.

Soi: http://s-o-i.org/1.1/TAS-09-65-12 Doi: crossef https://dx.doi.org/10.15863/TAS.2018.09.65.12

\section{INTRODUCTION}

Housing affordability is one of the most pressing socio-economic problems of all Commonwealth of Independent States (CIS) countries, as well as in Uzbekistan. In particular, today, in different countries of the world many local and international programs are being developed to provide the population with comfortable and affordable housing.

The solution of the problem depends on the increase in the volume of housing construction in Uzbekistan, the development of all the components of urban and rural infrastructure, as well as the improvement of the housing construction management system using the experience of the leading countries [8].

\section{URGENCY}

Despite the high population growth rates in Uzbekistan (over the years of independence there has been an increase of more than $9 / 4$ million), there is a steady increase in the housing stock in the country. If in 1991 one person had 12/4 square meters of the total area, then in 2016 this figure was up to 15.4 square meters with is grew up to 1.2 times.

In addition, the newly built houses in 2013 amounted to 10744.4 square meters. In 2014, 11419.4 square meters, in 2015 to 12052.7 square meters and in 2016 - 12726.9 square meters [9]. 


\begin{tabular}{l|lr|ll|ll} 
& ISRA (India) & $=\mathbf{1 . 3 4 4}$ & SIS (USA) & $=\mathbf{0 . 9 1 2}$ & ICV (Poland) & $=\mathbf{6 . 6 3 0}$ \\
Impact Factor: & ISI (Dubai, UAE) $=\mathbf{0 . 8 2 9}$ & PUHL (Russia) $=\mathbf{0 . 1 5 6}$ & PIF (India) & $=\mathbf{1 . 9 4 0}$ \\
& GIF (Australia) & $=\mathbf{0 . 5 6 4}$ & ESJI (KZ) & $=4.102$ & IBI (India) & $=\mathbf{4 . 2 6 0}$ \\
& JIF & $=\mathbf{1 . 5 0 0}$ & SJIF (Morocco) & $=2.031$ & & \\
\hline
\end{tabular}

Diagram 1. Newly renovated houses in Uzbekistan by 2013-2016 (square meters)

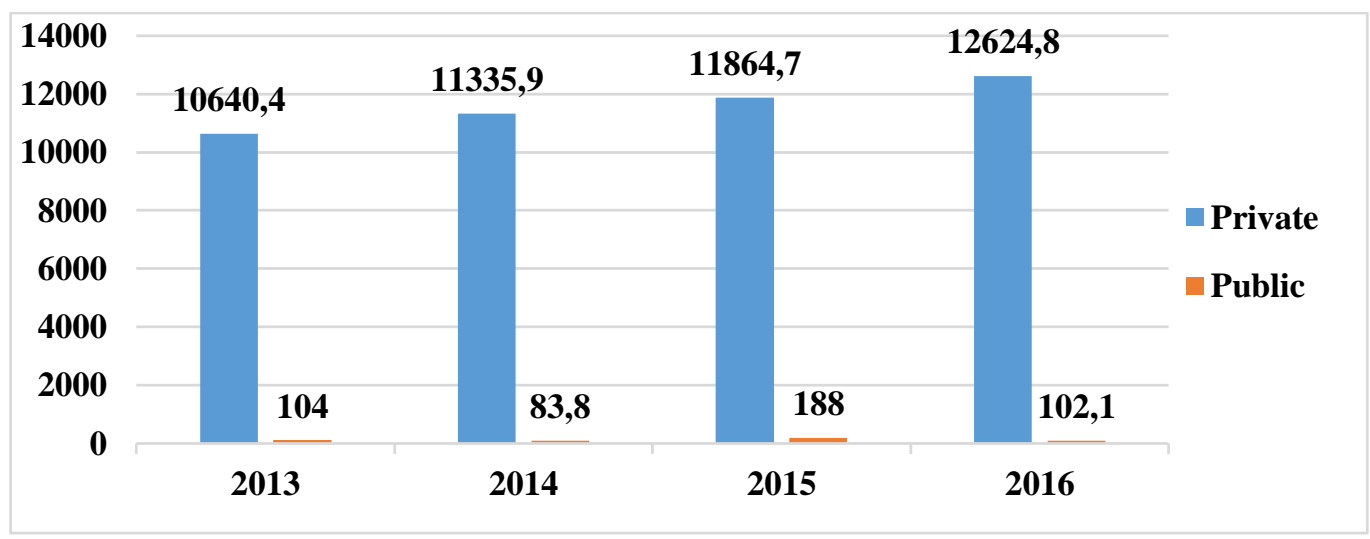

Source: Data of the State Committee of the Republic of Uzbekistan on Statistics [10].

By the First President of the Republic of Uzbekistan, 2009 The Resolution of 1167 "On Additional Measures to Expand the Housing Construction in Rural Areas" of August 3, sets out the scope of construction of individual housing projects on standard projects approved in accordance with general plans of rural settlements and architectural planning projects expanded conditions for the radical improvement of the living conditions of the rural population [1].

In particular, in the period from 2009 to 2016, in 1308 rural settlements, the total area was 9573 thousand square meters with 69557 comfortable houses were built and improved the living conditions of more than 83500 rural families. Also according to such projects in 201715000 houses and apartments were built.

Diagram 2. Exemplary projects in rural areas number of houses constructed for 2009-2017

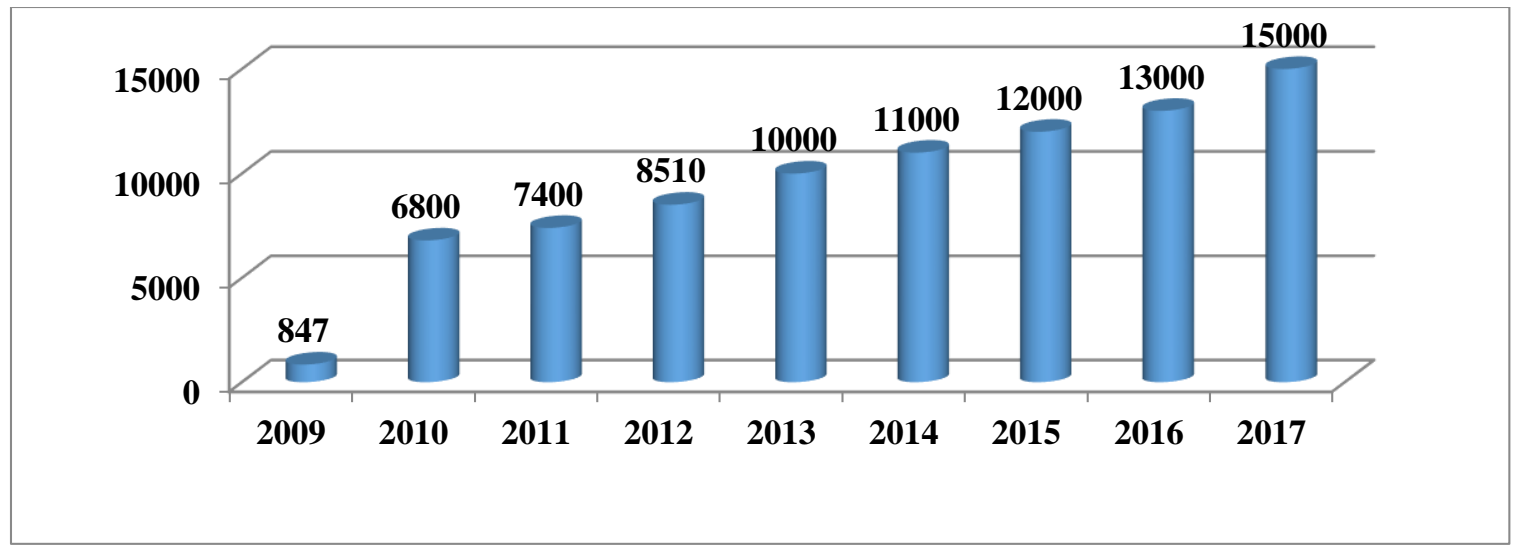

Source: Data of the State Committee of the Republic of Uzbekistan on Statistics [10].

Considering the analysis of investment in housing, this indicator is expected to reach USD 5640.7 billion in 2013. In 2014, 6692.8 billion soums were issued. In $2015,8443.1$ billion soums will be invested. and in 2016 - 11,126.7 billion soums. 


\begin{tabular}{|c|c|c|c|c|c|c|}
\hline Impact Factor: & $\begin{array}{l}\text { ISRA (India) } \\
\text { ISI (Dubai, UAE } \\
\text { GIF (Australia) } \\
\text { JIF }\end{array}$ & $\begin{array}{r}=1.344 \\
=0.829 \\
=0.564 \\
=1.500\end{array}$ & $\begin{array}{l}\text { SIS (USA) } \\
\text { PИHЦ (Russia) } \\
\text { ESJI (KZ) } \\
\text { SJIF (Morocco) }\end{array}$ & $\begin{array}{l}=0.912 \\
=0.156 \\
=4.102 \\
=2.031\end{array}$ & $\begin{array}{l}\text { ICV (Poland) } \\
\text { PIF (India) } \\
\text { IBI (India) }\end{array}$ & $\begin{array}{l}=6.630 \\
=1.940 \\
=4.260\end{array}$ \\
\hline
\end{tabular}

Diagram 3. The volume of investments into housing in 2013-2016 (billion soums)

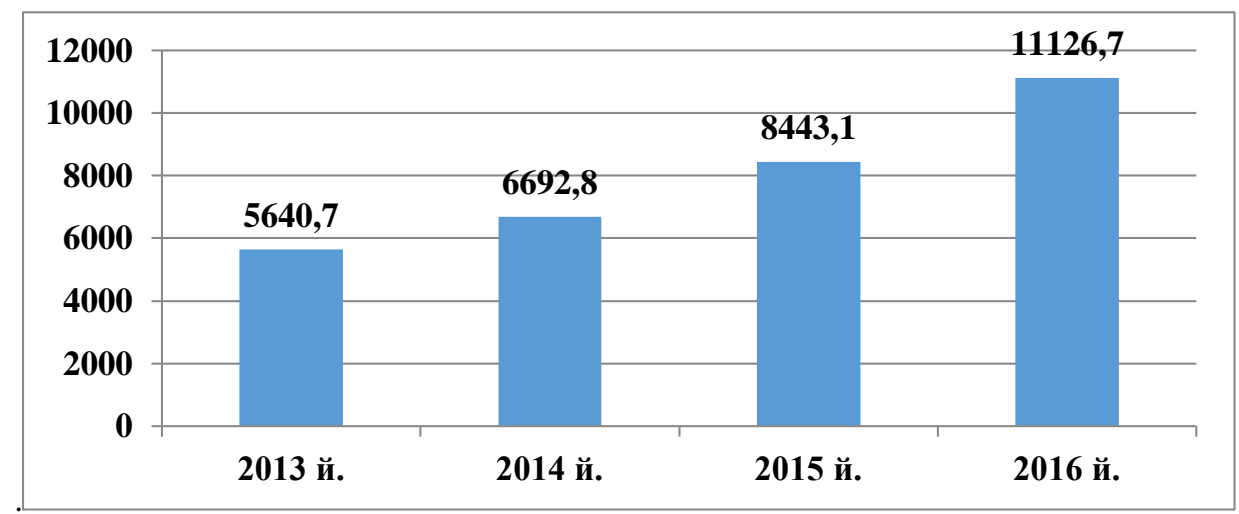

Source: Data of the State Committee of the Republic of Uzbekistan on Statistics [10].

Another positive result of the population's housing policy is to increase the level of development of the service sector in the country, to provide the population with new modern and quality services, to ensure economic growth and the role of the service sector in solving the problems of the population, the work being done to strengthen of the country.

Particularly, targeted state programs are being implemented to provide the rural population with drinking water and natural gas, as well as construction of trunk water and natural gas pipelines to increase the access of the population to safe drinking water and natural gas.

\section{THEORETICAL APPROCHES}

According to the President of the Republic of Uzbekistan Sh.Mirziyoev in 2016 Resolution of the Cabinet of Ministers of the Republic of Uzbekistan "On the Program of Construction of High-Rise Residential Houses on Updated Model for Rural Areas for 2017-2021" on October 21, in Uzbekistan, comfortable housing is being built on new model projects, taking into account the characteristics of national mentality and rural living conditions as well as high level of preferential lending and wide use of new types of energy-saving materials and equipment. These, in turn contribute to the reduction of the cost of new construction and the establishment of optimal prices for all layers of the population [2].

The national model of housing construction in Uzbekistan is distinguished by the following characteristics:

- development of rural housing construction is seen as a long-term strategic priority;

- designing a house for the population to have their own home-based mentality and regional traditions;

- high share of private housing construction in shared housing;
- the demographic factor has a significant impact on the housing demand (young families and population growth, household structure and structure);

- a comprehensive (scale) system of privileges and benefits for sustainable development of housing construction.

Today in our country a great deal of attention is paid to finding solutions to housing problems, identifying housing construction prospects, efficient use of housing and reconstruction. However, today's practice shows that housing construction does not take into account the optimization of the structure of the housing fund and the substantiation of market factors. This leads to imbalance in the housing of different categories of households, the deficit of some types of housing, and the excessive construction of other quartzs and, in general, the misuse of the country's housing stock [7].

This problem can be solved the optimal structure of housing construction can be modeled on this process. Modeling is related not only to the predictability of external factors, but also to the structure and scope of development of housing construction, but to the choice and justification of economic policy in the field of scientific and technological progress, investments, prices and other factors.

It is important to consider the length of the investment period in the construction of modern housing. The complexity, complexity and multidimension of the problem require a complex, systematic approach to the solution. The combination of information-logical modeling and economicsmathematical approaches makes it possible to develop the optimal model.

\section{ANALYTICAL PART}

The most commonly used and proven method used by experts today is simple and combinational groups based on information-logical modeling. There 
are some drawbacks along with the positive aspects of using these methods. Because they do not allow the effect of each factor. Therefore, in this study, we have been using additional economic and mathematical methods, which enables us to incorporate quality-theoretical analysis into quantitative terms. Thus, in all sectors of the regional construction complex, including housing, there is an opportunity for accurate mirror investigation [3;4].

Theoretical model of housing construction improvement can be as follows:

Here:

$$
S=f\left(T, O, \Pi, \ni, Э_{l}, Д, \kappa, C, \Gamma\right)
$$

$S$ - housing fund structure;

$T$ - technical (construction of living space with technical means and on what technological basis);

$O$ - organizational (interrelationships in the entire production chain - from banks to wholesale to construction materials, labor supply and so on);

$\Pi$ - legal (implementation of all legislative acts in the area of housing);

$\ni$ - economic (implementation of the basic rules of the market economy);

$\ni_{1}$ - ecological (observance of rules of sun and air insulation, safe placement, etc.);

Д - demographic (all factors - gender and age to national characteristics);

$K$ - cultural (compliance with all national traditions and traditions in architecture and design, inculcation of advanced international experience);

$C$ - social (accounting for material possibilities, government support and assistance);

$\Gamma-$ town-planning (observance of townplanning rules and procedures).

At the same time, it is necessary to address the most important issue in the field of housing - to ensure investment and the rational use of all material and technical resources.

The most important issue in the development of effective decisions on housing construction is the validity of optimality criteria, i.e:

- identification of key issues in housing construction;

- selection of the most important quantitative indicators;

- identification of the most important issues for a specific type of construction (brick or panel option), specific area (characteristics of the regional development), and the number of concrete housing (minimum 1-2, maximum 7), etc. .;

- simplicity of accountability for clarity for all professionals at all levels and regions;

- reflect the process in dynamics.

Approaches to the construction of housing construction should take into account organizational and economic changes with the formation of market relations $[5 ; 6]$ :
1) housing construction does not reach the target indicators but works on the terms of contractual relations with all participants of the investment project;

2) the price of the product, including the latest, ie, the cost of ready-made housing, is formed under the influence of market mechanisms;

3) Thus, the balance of demand and supply of housing is an essential element.

According to them:

1) the share of the state is sharply reduced;

2) the size of the non-state sector has increased and primarily due to the construction of individual homes by individual persons;

3) loss of management of a construction complex, for example in Tashkent, with the completion of the construction project;

4) regulation is carried out economically, although some aspects of administrative intervention are involved;

5) limitation of administrative interference.

Taking into account the abovementioned, housing construction can be structured in the following areas:

I. Development of a housing construction model with demarcation of time and duration of the construction;

II. The development of the multi-level model the opportunity to use this model in the city, district, at the enterprise level;

III. Establishing all the uncertainties and risks, primarily the investment block, the capacities of construction and installation companies and the production and technical base, and setting prices for different types of housing.

IV. Optimization of the housing fund structure, with different parameters, describes the district (territory) where the house is located from the number of rooms in the apartment.

Also, in order to identify potential households, it is important to take into account the level of hospitality that should be taken into consideration, not to mention how many years a person should work for the purchase of housing, but also the support of the state and the various structures.

The principle of housing construction, as well as a vector indicator, takes into account the following:

1) the structure of social housing construction;

2) the structure of commercial housing construction.

These two directions are independent. In the first case, the issue of allocating a flat free and privileged land is solved, and the second one is that individual individual builders will spend their own resources. However, in both cases, the government can provide "assistance". In the first case, public funds are used and various loans are attracted. In the 


\begin{tabular}{|c|c|c|c|c|c|c|}
\hline Impact Factor: & $\begin{array}{l}\text { ISRA (India) } \\
\text { ISI (Dubai, UAE } \\
\text { GIF (Australia) } \\
\text { JIF }\end{array}$ & $\begin{array}{l}=1.344 \\
=0.829 \\
=0.564 \\
=1.500\end{array}$ & $\begin{array}{l}\text { SIS (USA) } \\
\text { PИНЦ (Russia) } \\
\text { ESJI (KZ) } \\
\text { SJIF (Morocco) }\end{array}$ & $\begin{array}{l}=0.912 \\
=0.156 \\
=4.102 \\
=2.031\end{array}$ & $\begin{array}{l}\text { ICV (Poland) } \\
\text { PIF (India) } \\
\text { IBI (India) }\end{array}$ & $\begin{array}{l}=6.630 \\
=1.940 \\
=4.260\end{array}$ \\
\hline
\end{tabular}

latter case, builders can use different types of credit privileges, in absolute terms.

Vector vector - the required structure of social housing construction will serve to meet the housing needs of the population:

$V_{i}^{t}-t$ period $i$ - the size of the housing stock;

$\Pi_{i}^{t}-t$ period $i$-demand for housing.

$V_{i}^{t}-\Pi_{i}^{t} \rightarrow \min$, или 0

In this case, the Housing Demand Level indicator can be calculated using the following formula:

$$
\mathrm{S}=\frac{V_{i}^{t}}{\Pi_{i}^{t}}
$$

In this case, you can calculate depending on the number of flats required, as well as calculate by the number of 1,2,3,4 rooms and houses.

\section{CONCLUSION}

The procedure for calculating the aggregated structure of the social housing offered by us is essential for the implementation of socially-oriented and financially balanced housing policy in Uzbekistan.

The aggregated vector of commercial housing construction is based on different schemes of financing housing construction. This is to say that the selection of the right financing scheme usually determines the amount of funds ready by the subject for housing. Thus, the structure of commercial housing construction depends on the amount of capital spent.

So, we can see from the model model that investor (home buyer) $\hat{Z}$ seeks to get the most out of the total area, where the amount of funding for the Itype home fund; At the same time, the average cost per $1 \mathrm{sq} \mathrm{m}$ of housing for i-type housing.

$$
S=\frac{O_{i}^{t}}{L_{i}^{t}}
$$

At the same time, the model of optimization of the structure of commercial buildings will be shown in the following format:

- Number of flats of type $I$ in the form of ihousing stock in t-year;

- The average price per $1 \mathrm{sq} \mathrm{m}$ of the $\mathrm{i}$-series in the t-year;

- Type i-type of housing with type $\mathrm{j}$ of the year $\mathrm{t}$

$$
K_{j i}^{t} \cdot \bigsqcup_{i}^{t} \cdot \mathrm{O}_{i}^{t} \rightarrow \min
$$

Taking all accounts it is possible to conclude that this article is based on the creation of economic mathematical models and the use of special mathematical methods to build a common model of optimal construction of housing in Uzbekistan and minimize all computing operations using modern computer software.

\section{References:}

1. (2009) Resolution of the President of the Republic of Uzbekistan "On Additional Measures to Expand the Housing Construction in Rural Areas". N 1167. The 03.08.2009.

2. (2016) Resolution of President of the Republic of Uzbekistan “On the Program of Construction of High-Rise Residential Houses on Updated Model for Rural Areas for 2017-2021". 21.10.2016.

3. E. Ostrom. (2010) Working Together Collective Action, the Commons, and Multiple Methods in Practice. 2010.

4. Stepanov S.A. (2009) Immovable property in civil law. - M., 2009.

5. Nurimbetov R.I, Davletov I.Kh. (2017) Improvement of the structure of housing construction in Uzbekistan. Housing strategies. Russian Journal of Housing strategy. Part 4. Number 1. 2017.
6. Nurimbetov R.I, Salaev S.K. (2016) Strategy of development of organizational and economic mechanism of the housing market. Architecture. Construction. Design. Scientific and Practical Jurnal. T., 2016.

7. Davletov I.Kh. (2017) Modern trends in the development of housing and communal services in Uzbekistan. T., 2017.

8. Khasanov T.A. (2017) Housing fund as an object of management. Architecture. Construction. Design. Scientific and Practical Jurnal. T., 2017.

9. Khasanov T.A. (2018) Tendencies of housing sphere development and feature of housing fund management in Uzbekistan. Theoretical \& Applied Science. International Scientific Journal. Philadelphia, USA. 3.06.2018.

10. (2017) Statistical collection of the State Committee of the Republic of Uzbekistan on Statistics. 2017. 